\title{
Politicians, Professionalization and Anti-politics: Why we want leaders who act like professionals but are paid like amateurs
}

A slightly amended version of this paper is forthcoming in Policy Sciences (accepted for publication on 4 June 2018)

\author{
Paul Fawcett \\ Institute for Governance and Policy Analysis \\ University of Canberra \\ paul.fawcett@,canberra.edu.au
}

http://orcid.org/0000-0002-8059-2813

\author{
Jack Corbett \\ Department of Politics and International Relations \\ University of Southampton \\ j.corbett@,soton.ac.uk
}

http://orcid.org/0000-0003-2005-7162

\begin{abstract}
Why are politicians so unpopular? One common explanation blames a professionalized political class that is increasingly detached from "ordinary citizens". But, there is very little empirical investigation of what it is about the professionalization of politics that engenders distrust. This article uses 12 focus groups and 15 interviews with civil servants from the Australian Public Service - 'insiders' with first-hand knowledge and experience of the political system - to reflect on political professionalization and its
\end{abstract}


impacts. As a group, civil servants' views on this question remain largely unexplored yet their proximity to the political process gives them a distinct vantage point from which to reflect on current explanations for rising anti-political sentiment. We find both positive and negative attitudes towards professionalization that destabilize prevailing explanations: on the demand-side, civil servants share first-hand experience and knowledge of how the political process works but remain cynical about politicians; whilst, on the supply-side, they value governing competence more than demographic representation yet still prefer more amateur politicians. Our reflections on these findings highlight contradictory expectations: we want politicians who act like professionals, but who are paid like amateurs.

\section{Keywords}

politicians; anti-politics; professionalization; civil servants; Australia

\section{Acknowledgements}

We acknowledge financial support from the IGPA Research Incentives Fund and the Australian Research Council (DP120104155). We would like to thank Thaneshwar Bhusal, Marion Carter, Lain Dare and Lyndall Hasselman for their help in facilitating the focus groups, and Jacob Deem, Magali McDuffie and Caroline Sinclair for additional research assistance. We would also like to express our particular thanks to the government agencies who gave us their permission to run the focus groups and the public servants who gave their time to participate in this study. Finally, we would like to thank the journal's reviewers for their suggestions on how to improve the article as well as those who provided feedback on an earlier version of this paper at the IGPA 
Research Symposium on 'Populism: what's next for democracy?' (University of Canberra).

\section{Introduction}

Politicians, as a group, have never been popular but cynicism and disaffection towards them appears to be on the rise. This trend is captured in numerous public opinion surveys (e.g. Norris 2011; Clarke et al. 2018; Evans and Stoker 2016; Stoker et al. 2017) and in the tenor of public discourse surrounding political scandals and abuse of entitlements (e.g. Allen and Birch 2011; Negrine and Bull 2015). A growing body of scholarship has sought to explain this phenomenon (for a review see Corbett 2016). One common explanation is that the professionalization of politics and politicians is a cause of anti-politician (rather than anti-politics) sentiment (Stoker 2006; Hay 2007; Hay and Stoker 2009; Flinders 2012; Wood and Flinders 2014; Papadopoulos 2013; Fawcett 2014; Clarke et al. 2018).

Intuitively, this argument makes sense. Numerous studies have confirmed that professionalization is a growing trend in advanced liberal democracies (e.g. King 1981; Riddell 1995, 1996; Cairney 2007; Coghill, Colleen and Steinack, 2012; Barber 2014; Allen and Cairney 2015). We know that politicians increasingly treat their job as a career, enter the profession younger, are drawn from a narrower range of backgrounds, and receive higher salaries and associated perks. The parallel rise in anti-political sentiment since the late 1970s and early 1980s appears to support this trend (Moss et al. 2016). 
Existing studies posit three main propositions for rising levels of professionalization and its negative impact on public attitudes towards politicians. From the 'supply-side', the literature on descriptive representation (e.g. Cowley 2014; Campbell and Cowley 2014; Lapinski et al. 2016) finds that the public want politicians who are more 'like them'. From this perspective, rising anti-politician sentiment is caused by politicians who are demographically unrepresentative of the population 'at large'. Professionalization has contributed towards this trend by creating a self-referential and cosseted elite. Politicians are 'out of touch' from the interests of 'ordinary citizens' because they neither look nor behave like them.

Another 'supply-side' explanation is derived from the depoliticization literature (e.g. Hay 2007; Flinders and Buller 2006; Wood and Flinders 2014; Fawcett et al. 2017). In this view, politicians having abrogated their power to experts and arms-length bodies. Whilst politicians have been all too willing to defer to a technocratic elite, citizens have become increasingly critical of the neoliberal policy paradigm and what it represents. The proposition is that, if politicians were not as compromised by special interests and as favourably disposed towards the depoliticization project, then citizens would be less disaffected with them and the political process more generally.

Conversely, from the 'demand-side', the claim is that changing societal values, especially about civic participation (see Putnam 2001), has resulted in democratic freedoms being taken for granted (e.g. Flinders 2012). The proposition here is that, if citizens were better educated about the democratic system, then they would be less critical of its failings. In part, these divergent propositions highlight that professionalization is a multi-dimensional concept. This important caveat aside, further 
investigation is warranted given both the theoretical and practical significance of each explanation, and their regular repetition in scholarly and popular debate.

This article addresses these propositions by drawing on extensive interview and focus group data with civil servants working in the Australian Public Service (APS). ${ }^{1} \mathrm{We}$ focus on civil servants because they have an intimate understanding of the political process: theirs is a highly nuanced 'insider' perspective on political professionalization. If the demand side argument is correct, we would expect 'insiders' to be more sympathetic towards politicians than citizens. Conversely, if the supply side arguments are correct, we would expect 'insiders' to be able to pin point what it is about professionalization that has altered political representation for the worse. The views of 'insiders', while rarely canvassed, offer a unique vantage point from which to interrogate these propositions (Boswell et al. 2018). To draw out this perspective we conducted interviews with senior civil servants who all shared a proximate working relationship with politicians and ministers. We also undertook focus groups with junior civil servants who observed the workings of democratic politics from close range. Our approach gave participants the opportunity to unpack what they understood by professionalism as well as explore and comment on its different facets in an open dialogue with minimal intervention. By focusing on 'insiders', whose proximity to power varied, we were able to tease out nuances in how our civil servants perceived politicians and the political process more generally.

We find evidence to question the 'demand-side' claim that if people better understood politics then they would be less critical of it. Instead, we find that 'insiders' have strong views about the failings of the democratic system and what might be done about it (cf. 
Boswell and Corbett 2015). But, we do not find evidence that wholeheartedly supports the 'supply-side' propositions either. Our participants often held contradictory beliefs about what doing the job of politics entails: on the one hand, they want their politicians to observe professional norms and standards of conduct, have appropriate levels of training and expertise, work long hours and be honest and transparent in their dealings; but, on the other hand, they bemoan paying salaries commensurate with the private sector, believe that most perks and entitlements are unwarranted, and hold a preference for politicians who 'speak their mind' and come from outside the party political system. In short, they want politicians who are both 'like them' but also better than them (cf. Kane and Patapan 2012, chapter 10).

Recognition of a preference for politicians who act like professionals but are paid like amateurs is, we argue, a significant contribution to existing debates about the causes of anti-politics. Specifically, because we find these views among 'insiders', reforms that target either the demand or supply side in isolation are likely to have limited effect. Instead, our findings suggest alternate explanations of why citizens feel an antipathy towards politicians that sees the problem as an insoluble 'trap' inherent to representative politics (see especially Kane and Patapan 2012; Medvic 2013).

The article develops this argument over four parts. First, we discuss the literature on the professionalization of politics and rising careerism among the political class. Second, we briefly survey the current literature on anti-politics in order to situate our contribution, including how and why we might expect 'insiders' to align (or not) with the three propositions that we identify from this literature. Third, we outline our research design, justify our choice of civil servants as a suitable group with which to 
pursue our particular interests and locate our study within the Australian context from which it is drawn. We also show how qualitative research can add depth to existing studies of anti-politician sentiment (which have thus far predominantly relied on surveys). Fourth, we draw on this rich empirical data to flesh out the different meanings and dimensions of professionalization amongst civil servants. We conclude by reflecting on our empirical study and what can be inferred from it about the three propositions that have dominated the anti-politics debate, particularly highlighting the significance of our contribution with respect to the professionalization of politicians.

\section{Politicians and the Professionalization of Politics}

The label 'professional politician' is rarely a compliment, underscoring the obvious link with democratic disaffection discussed above. Indeed, as Hay and Stoker (2009, 228230) highlight, it is generally employed as a pejorative label in modern politics, as evidenced by the coverage of the expenses scandal in the UK (Allen and Birch 2011; Negrine and Bull 2015). The public are said to feel robbed by a cadre of professionals who have colluded in their own self-interest and at the expense of everyone else (an example of what Hibbing and Theiss-Morse (2002) call 'stealth' democracy).

The confounder is that professionalism (or professionalization) is a highly contested term in contemporary society (for a review see Evetts 2013). We do not wish to revisit the perennial discussion about what does and does not constitute a profession—or even 'full' or 'semi' profession-here (but, see Abbott 2014; Jones 2008). For now, the important point is that until recently the term 'professional' referred to a select few occupations, including doctors, lawyers and engineers. These forms of work were designated a distinct skillset born out of an intensive training that set them apart from 
other occupational groups by virtue of their 'mental labour' and 'model of technical rationality' (Schon 1983 cited in Noordegraaf 2007, 765). This distinction then became the basis upon which certain professional groups justified better work conditions. Neither civil servants nor politicians were professionals in this definition. But, as professionalism came to be revered and applied more widely, Wilensky (1964) was prompted to ask whether we were witnessing the 'professionalisation of everyone'. Today, virtually all sectors are seeking to professionalize so as to legitimize demands for their function (Noordegraaf 2007, 761), and politicians are typically no different.

The seminal modern theorist of the impact of professionalization on politics and politicians is the German sociologist Max Weber. In his famous essay 'Politics as a Vocation', Weber (1968 [1919]) distinguishes between politicians who live 'off' politics - it is their primary means of employment and income - and those who live 'for' politics - it is something pursued in the service of a cause, with material support largely drawn from private means (see Kelley 1998, 339; Jones 2008, 247). Weber was wary about the impact of professionalization on political life. Echoing his view that political leadership required a certain charisma that could offset the legal-rational authority of the bureaucratic state, Weber believed that the landed gentry were best placed to govern democratic publics on the grounds that they did not need to be remunerated and so could be relied upon to make decisions that reflected the broader public good. A preference for politicians who are independent, wealthy and 'above corruption' is echoed in the rhetoric of populist leaders like Italy's Silvio Berlusconi and America's Donald Trump (Mudde 2007; Mudde 2013, 1; McDonnell 2015, 719; Albertazzi and McDonnell 2015). Put simply, the argument is that intelligent and dutiful 'amateurs' make the best democratic leaders. 
Various strands of literature from both political science and law have also argued that greater professionalism will revive the public's faith in politics and politicians. The Inter-Parliamentary Union's guide to good practice endorses 'recovering public confidence in the integrity of parliamentarians, through enforceable codes of conduct and reforms in party funding' and 'adequate salary for members; register of outside interests and income, enforceable limits on transparency in election fundraising and expenditure' (Beetham 2006: xi, 10; Coghill, Colleen and Steinack, 2012; Coghill, Sampford and Smith 2012; Lewis and Coghill 2016). In this view, if politicians acted, or where forced to act, more like professionals, then the public would consider their actions and practices more palatable.

Putting normative preferences to one side, it is widely accepted that professionalization is now a ubiquitous feature of modern liberal democracies (see King 1981; Riddell 1996; Cairney 2007; Howarth 2013; Barber 2014; Allen and Cairney 2015). Over the past several decades, political scientists have developed sophisticated tools for measuring professionalization trends: from income and monetary incentives (e.g. Borchert and Zeiss 2003; Eggers and Hainmueller 2009; Best and Higley 2010) to the quality and volume of law making (e.g. Beckman 2007). Much of this work is quantitative. It consistently highlights that as career trajectories narrow, politicians increasingly come from a similar background: as a group, they remain stubbornly "male, pale and stale" (white, male, middle-aged and middle-class). It also hints at the considerable movement between 'politics facilitating' positions (Cairney 2007, 212) and the informal networks of personal connections that shape everyday political practice. The effect of these trends is that politicians are said to be less representative 
of ordinary citizens than in the past. Intuitively, this ought to give rise to the democratic disaffection that anti-politics scholars have observed over the past two decades.

\section{Explaining How Professionalization Shapes Citizens' Attitudes Towards}

\section{Politicians}

Hay (2007; see also Hay and Stoker 2009, 234-235) argues that two prevailing explanations exist for the growing 'gap' between what citizens expect from democratic politics and what it delivers: 'demand-side' explanations and 'supply side' explanations.

\section{Table 1}

Explaining Rising Disaffection: "Demand side" and "supply side" accounts

\begin{tabular}{|c|l|l|}
\hline & \multicolumn{1}{|c|}{ Problem } & \multicolumn{1}{c|}{ Solution } \\
\hline & $\begin{array}{l}\text { An increasingly apathetic citizenry } \\
\text { correlates with an increasingly } \\
\text { corrosive form of public cynicism }\end{array}$ & $\begin{array}{l}\text { Citizens need to re-engage with the } \\
\text { political process }\end{array}$ \\
\hline क्षे & $\begin{array}{l}\text { The professionalization of politics } \\
\text { and depoliticization has stymied } \\
\text { citizen engagement and interest in } \\
\text { politics }\end{array}$ & $\begin{array}{l}\text { Reinvent a 'politics for amateurs' } \\
\text { where decision-making is more } \\
\text { participatory, collaborative and } \\
\text { deliberative }\end{array}$ \\
\hline
\end{tabular}

If we drill deeper into this literature to investigate how these perspectives explain citizens' disapproval towards politicians (rather than politics writ large), we find three propositions that seek to link these two trends:

- Proposition 1 (supply-side): the public want politicians who are more 'like them'; political careerists are out of touch with the views and lifestyles of ordinary citizens by virtue of their background and socialization into the 'Westminster club' (e.g. 
Rush and Giddings 2011; Cowley 2014; Campbell and Cowley 2014; Lapinski et al. 2016). As 'insiders', we might expect civil servants to place a higher value on professional standards than politicians coming from different demographic backgrounds than their electorates.

- Proposition 2 (supply-side): if politicians were less enamoured by depoliticized forms of authority and not compromised by special interests then citizens would be less disaffected with their performance (e.g. Hay 2007; Flinders and Buller 2006; Marsh et al. 2016, 388; Wood and Flinders 2014; Fawcett et al. 2017). As 'insiders', we might expect civil servants to be critical of special interests exerting 'undue influence' over the policy process and be more favourably disposed towards depoliticized forms of authority that make long-term evidence-based decisions.

- Proposition 3 (demand-side): if citizens better understood democracy and its strengths compared to the other alternatives on offer then they would be less critical of its shortcomings and the shortcomings of its leaders (eg Flinders 2012). As 'insiders', we might expect civil servants to show more understanding and empathy towards the democratic system and its leaders given their proximity and first-hand knowledge of the political system.

From the supply-side, the solution is often seen to lie in a return to a "politics for amateurs' (Stoker 2006) where either recruitment practices are changed so that politicians look more like the constituents that they represent or public debate is actively encouraged so that politics is represented as an open and contingent phenomenon, rather than something that is consigned to the realm of fate or necessity. More radical variants of the 'supply-side' argument can be found in the burgeoning literature on deliberative and participatory democracy (e.g. Curato et al. 2017). In this scenario, the professional 
politician is unfavourably juxtaposed with the passionate or ideologically driven citizen-legislator, dutiful landed gentry of the late nineteenth century, or the localized community activist (Neblo et al. 2010).

These propositions also have implications for how 'insiders' might view anti-politics. If the supply side arguments are correct then we would expect 'insiders' to be able to identify the 'root cause' of the political disaffection caused by the professionalization of the political class. Alternatively, from the 'demand-side', the problem is seen to rest with a free-riding public who need to keep up their end of the democratic bargain. If citizens became more involved in the political process then politicians would be more responsive to their needs and concerns. If the demand side argument were correct then it would be reasonable to expect that 'insiders' would be more sympathetic towards politicians than citizens.

\section{Method and Data}

This study seeks to shed light on each proposition. But, given the divergent causal explanations, a particular set of data sources is required that cannot be currently found in existing survey work. To address the 'demand-side' belief that if citizens knew more about how politics actually works they would be less disaffected with the outcome, we need to engage with the views and perspectives of political 'insiders' (see Boswell et al. 2018). One option is to ask politicians themselves, but this work has already been done (see Reheer 2006; Jones 2005; Corbett 2015). It reveals that MPs see themselves as facing contradictory and seemingly irreconcilable expectations about what democratic politics can and should deliver. This work thus reveals what it is like to be a political professional but cannot shed light on how that performance is received. 
To shed light on this question, this study therefore focuses on the views and perspectives of civil servants from the APS who are both 'professional' in the modern sense, but also one step removed from the political game. To be sure, this critical distance can be small, especially for senior civil servants. We expected, for example, that our participants would be more sympathetic towards politicians than the average citizen. Or, were they to be critical, their views would be based on disagreements over substantive policy issues rather than mainstream anger at the abuse of entitlements, for example. What will become clear, however, is that the exact opposite appears to be true: close proximity with political processes has actually re-enforced their negative views and the professionalization of politics is central to these concerns (cf. Boswell and Corbett 2015). Indeed, nearly every single adjective used by our participants to describe politicians has a negative connotation: untrustworthy, power hungry, unreliable, self-serving and dishonest. As a result, we contend that the views and perspectives of civil servants have hitherto untapped value as research subjects. At one and the same time, they are both the metaphorical 'fly on the wall' and the 'neutral professional' who does not share any explicit partisan or personal loyalty to any one particular politician. Theirs is a unique and under-researched perspective that can shed important light on more general questions about democratic disaffection.

Our data is drawn from Australia where several surveys have noted declining levels of trust in political institutions. ${ }^{2}$ For example, results from the 2016 Australian Election Study found record low levels of satisfaction with democracy and trust in government (Cameron and McAllister 2016, 75; see also Edelman Trust Barometer 2017; Evans and Stoker 2016). ${ }^{3}$ Martin $(2012,217)$ has also noted that the younger cohorts are more 
likely to be politically disengaged than older ones (but see Stoker et al. 2017). This supports similar findings from earlier studies (e.g. Papadakis 1999). As Gauja (2015, 23) concludes: 'Like many other advanced industrial democracies, the Australian system of government has not escaped the climate of disaffection and disillusionment with representative politics that has permeated academic and public discourse in recent years' (see also: Marsh and Miller 2012).

More narrowly, Australia's politicians have also come under scrutiny. Taking the 'long view', Jones (2005) documents an enduring history of cynicism and distrust towards Australia's politicians dating back to Lafitte's (1958) study of factory workers in Melbourne (see also Dickenson 2013). For example, Mayer et al.'s (1960) study of more than 700 'Letters to the Editor' (in the wake of the 1959 Richardson Report on Parliamentary Salaries) concluded that there was a consistent distrust towards politicians, their motivations, their morality and their capacities. Poll data also supports these findings: since 1986, Federal MPs have never achieved an approval rating above $20 \%$ for their 'ethics and honesty' ('very high' or 'high' rating) with the average result coming in at $14 \%$ (Roy Morgan 2017). ${ }^{4}$ Thus, Jones $(2005,119)$ concludes that: 'Political cynicism and distrust in government and politicians has been a prominent feature of Australian political life since colonial times.'

Whilst this 'long view' emphasizes ongoing disaffection, the particular form that this cynicism takes has evolved in response to the changing form and nature of anti-politics sentiment (Clarke et al. 2018). For example, Leigh (2002, 47, emphasis added; see also Crosby 2016) has noted a discernible shift in attitudes towards the 'political class' over the more recent period: 
Yet when it comes to opinions as to the ethics and honesty of Australian politicians, or trust in the federal government, the standing of Australian politicians has clearly fallen. While many commentators may overplay the extent of the drop, the fact that it has occurred is not in question.

Elsewhere, Bean $(2012,105)$ has noted that: ‘...many Australians....are not confident that elected politicians and appointed public officials can be trusted' (see also: Burchell and Leigh 2002). In this way, the Australian case mirrors global trends at the same time as it presents a somewhat unique case because, unlike the US or Europe, it has largely remained largely unaffected by the global financial crisis (Hill 2012). As a result, Australia has not experienced the types or levels of austerity common in other liberal democracies where anti-political sentiment has often been associated with the economic downturn and rising inequality. In other words, while it is not singularly exceptional (Dowding 2017), the Australian case is nevertheless interesting because contemporary political disaffection cannot be as easily explained away by the economy. Rather, we must look to explanations that emphasise deeper, longer-term, democratic trends.

To interrogate competing explanations, we conducted interviews and focus groups with serving civil servants from the APS. Interviews and focus groups have long been used to study political attitudes and anti-political sentiment (e.g. Stoker et al. 2016; Brett and Moran 2006). Whilst survey based research can elicit individual level attributes, interviews and focus groups gave the participants in this study the opportunity to unpack and discuss at length their different attitudes towards professionalization. The focus groups were also effective at generating a dialogue between a group of people 
who had come together to talk about a particular issue (e.g. Smithson 2000; Cyr 2016; Vromen et al. 2016). Whilst this feature of focus group research has advantages, it can also provoke certain inhibitions amongst participants. It is impossible to guard against this entirely but, with this consideration in mind, facilitators were instructed to focus on what Stoker et al (2016) (building on Kahneman (2011)) have described as 'slow thinking' - reflective and deliberative modes of cognition. We also deliberately kept the focus group size relatively small to provide space for reflective discussion and to leave enough time for facilitators to encourage dialogue. In practice, this meant a more analytic and less intuitive or reactionary understanding of the problem as might be more commonly found in survey research. To be sure, relative to a representative survey the focus on civil servants suffers from an external validity problem. In qualitative research, however, this specifically chosen and highly informed knowledge is a strength because it generates a much deeper and substantive discussion that aids theoretical and conceptual development.

In stage one, 12 focus groups were conducted with approximately five junior civil servants in each between August and September 2016 (see the Supplementary Information for further detail on the data collection and analysis). The focus groups lasted approximately 60 minutes each. Two further focus groups were held with the focus group moderators to help generate meta-empirical insights. Twelve focus groups with 59 civil servants was deemed a reasonable number for generating a range of insights into politicians and their professionalization. In stage two, we conducted fifteen semi-structured interviews with serving or recently retired senior civil servants in two separate tranches (ten interviews between November 2016 and January 2017 and five between July 2017 and August 2017). ${ }^{5}$ The interviewees were drawn from a mix of 
central and line agencies. In total, we transcribed seventeen hours of interview material. We stopped doing any further interviews once we had reached the point of data saturation. All of those we interviewed had experience working in close proximity to politicians, many in multiple different roles and capacities (e.g. in Parliamentary Committees, ministerial offices, as lobbyists, or through personal association). Participants in the focus groups and interviews were asked the same seven 'open-ended' questions about politicians. The questions were designed to 'open up' a dialogue about politicians and their professionalization, rather than act as a 'strict' template for discussion. The data collection occurred over a 12-month period but it is unlikely that the time taken would have had any discernible impact on the results because the questions were sufficiently abstract and there were no significant changes in government during this period.

Full transcripts from the focus groups and interviews were prepared by a research assistant and imported into Nvivo. The focus group transcripts were coded first, followed by the interviews. The data was akin to open-ended responses with interaction among the participants in the case of the focus groups. Initially, the transcripts were read and a 'long list' of codes was produced around different aspects of 'political professionalization'. Overlapping, duplicate or similar codes were subsequently deleted or merged into one another after which the codes were grouped into broader themes. The coders met at several intervals during this process to discuss their codes, the themes and the placement of codes into particular themes. Once complete, the data was sorted by thematic group and the coded data within each thematic group was analysed to identify whether a participants' comment was: (a) positive or negative; and (b) whether it was being defined as an attribute of 'professional politicians' or 'amateur politicians'. 
The results from this analysis formed the basis for the findings and their presentation (see Table 2 below).

The diversity of experience generated by combining focus group with interview data produced an extremely rich dataset of experienced 'insiders' from junior and senior levels within the APS. To be sure, relying on 'insiders' has its limitations; we can infer, for example that citizens might hold similarly contradictorily views to those described here but only further empirical work can bear this out. But, given the claims made in the literature about how proximity to power shapes how people view the political process, and the relative dearth of empirical work on the views and perspectives of 'insiders', theirs is a unique vantage point.

\section{Politicians and the Multiple Meanings of Professionalization}

There were four main ways in which our participants discussed the professionalization of politicians: motivation and recruitment; working competencies; working values; and working conditions. Our analysis revealed important positive and negative attributes towards politicians as professionals and politicians as amateurs in each of these areas. The larger distinction between professional and amateur politics that emerges from our data directly speaks to the 'supply side' accounts of democratic disaffection outlined in Table 1. Negative perceptions towards professional politicians who are seen as 'out of touch', self-serving and party apparatchiks was often contrasted with the positive attributes of amateur politicians detailed in Table 2 below. As discussed earlier, Propositions 1 and 2 are particularly pertinent here where demands emerge for more politicians who are uncompromised by special interests and more like 'one of us'. However, as 'insiders', civil servants also spoke about the positive attributes of being a 
professional politician as well as the negative attributes of being an amateur. Reflecting on Proposition 3, this may demonstrate an increased awareness and understanding towards politicians and the political process. For example, civil servants recognized that professional politicians can achieve results in ways that amateur politicians often cannot because they have developed the necessary working competencies and skillset to execute their craft. As a professional politician, maintaining one's principles at the same time as preserving one's position was described as a 'balancing act' that was difficult to achieve in practice. However, as we discuss in further detail below, proximity to the political system does not always translate into greater empathy: a question that goes to the heart of demand-side accounts of democratic disaffection. The remainder of this section of the article uses material from the focus groups and interviews to further unpack the results presented in Table 2. 
Table 2

Professionalism in Politics: Meanings and Characteristics

\begin{tabular}{|c|c|c|c|c|}
\hline & $\begin{array}{c}\text { The Professional Politician } \\
\text { (positive) }\end{array}$ & $\begin{array}{c}\text { The Professional Politician } \\
\text { (negative) }\end{array}$ & $\begin{array}{c}\text { The Amateur Politician } \\
\text { (positive) }\end{array}$ & $\begin{array}{c}\text { The Amateur Politician } \\
\text { (negative) }\end{array}$ \\
\hline $\begin{array}{l}\text { Motivation and } \\
\text { Recruitment }\end{array}$ & $\begin{array}{l}\text { Goal-oriented } \\
\text { Enters young, spends most of } \\
\text { their life in politics and works } \\
\text { for 'the party'. }\end{array}$ & $\begin{array}{l}\text { Party-oriented } \\
\text { Perceived as 'different' from the } \\
\text { average citizen but similar to } \\
\text { their colleagues. }\end{array}$ & $\begin{array}{l}\text { Duty-oriented } \\
\text { Enters politics out of 'dutiful } \\
\text { concern' or a 'calling'. Had a } \\
\text { non-political career, represents } \\
\text { the 'ordinary citizen', and is not } \\
\text { concerned with incumbency. }\end{array}$ & $\begin{array}{l}\text { Self-oriented } \\
\text { Enter politics for 'fun' or } \\
\text { something 'to do' rather than } \\
\text { deep conviction. Still different to } \\
\text { average citizens in terms of } \\
\text { background. }\end{array}$ \\
\hline $\begin{array}{c}\text { Working } \\
\text { Competencies }\end{array}$ & $\begin{array}{l}\text { Tough and uncompromising } \\
\text { An experienced and seasoned } \\
\text { negotiator who is 'results' } \\
\text { focused. A skilled } \\
\text { communicator. Takes } \\
\text { responsibility and is willing to } \\
\text { make tough decisions. } \\
\end{array}$ & $\begin{array}{l}\text { A 'political animal' } \\
\text { Lacks talent or vision. Benefits } \\
\text { from incumbency rather than } \\
\text { expertise. Leverages networks } \\
\text { and personal loyalty. Crafty and } \\
\text { calculating. Breaks promises. }\end{array}$ & $\begin{array}{l}\text { Independent } \\
\text { Values 'common sense' } \\
\text { decision-making, works with } \\
\text { autonomy, and develops a } \\
\text { 'personal connection'. Relies on } \\
\text { personal experience, 'everyday' } \\
\text { and 'average' characteristics }\end{array}$ & $\begin{array}{l}\text { Ineffectual } \\
\text { Lacks the network and } \\
\text { organization of the party } \\
\text { functionary. Tends to pursue ad- } \\
\text { hoc policy goals. Has limited } \\
\text { capacity to 'follow through' on } \\
\text { promises. }\end{array}$ \\
\hline $\begin{array}{c}\text { Working } \\
\text { Values }\end{array}$ & $\begin{array}{l}\text { Public good and personal } \\
\text { integrity } \\
\text { Seeks to realize specific policy } \\
\text { goals. Acts according to } \\
\text { professional norms and } \\
\text { standards. They always balance } \\
\text { the 'right thing' against their } \\
\text { own self-preservation. } \\
\end{array}$ & $\begin{array}{l}\text { Personal advancement } \\
\text { Works only to achieve own ends } \\
\text { and to preserve personal status. } \\
\text { Corrupted by a 'political system' } \\
\text { that rewards party loyalty with } \\
\text { incumbency and job security. } \\
\text { Out of touch with what the } \\
\text { general public wants/needs. }\end{array}$ & $\begin{array}{l}\text { Independence and frankness } \\
\text { Autonomy from the system } \\
\text { reinforces confidence in the } \\
\text { politician's personal integrity } \\
\text { and ethics, values open, truthful } \\
\text { and personal expressions of } \\
\text { political values, commitments } \\
\text { and challenges }\end{array}$ & $\begin{array}{l}\text { Lacks 'win at all costs' } \\
\text { mentality } \\
\text { Has little personal stake in the } \\
\text { 'game' and therefore cares less. } \\
\text { Too 'soft' to make a real } \\
\text { difference. Easily brushed aside } \\
\text { by the 'system' }\end{array}$ \\
\hline $\begin{array}{c}\text { Working } \\
\text { Conditions }\end{array}$ & $\begin{array}{l}\text { Hard-working } \\
\text { Long hours and poorly } \\
\text { remunerated compared to other } \\
\text { senior positions (e.g. bankers or } \\
\text { lawyers). They are entitled to } \\
\text { their higher than average wages. }\end{array}$ & $\begin{array}{l}\text { Self-serving } \\
\text { Well paid compared to the } \\
\text { average citizen and takes } \\
\text { advantage of considerable perks } \\
\text { and entitlements. }\end{array}$ & $\begin{array}{l}\text { Self-sacrificing } \\
\text { Financially self-sufficient and } \\
\text { therefore above corruption. } \\
\text { Could make more money } \\
\text { elsewhere. }\end{array}$ & $\begin{array}{l}\text { Part-time } \\
\text { Costs the taxpayer little but } \\
\text { provides little in return. Often } \\
\text { side-tracked by their other } \\
\text { interests - business and personal. }\end{array}$ \\
\hline
\end{tabular}




\section{Motivation and Recruitment}

Motivation and recruitment was a recurrent theme in our data. Whilst most of our interviewees recognized that people entered politics for a variety of different reasons family dynasty, idealism, or out of a 'thirst for power' - most also believed that, at their core, politicians entered politics for the 'right reasons' - out of a 'sense of public good' or a 'passion for change'. The rub is that they also argued that these ideals 'get lost very quickly' as 'somewhere in the coal mine their faces get blackened'.

The most negative views were reserved for 'career politicians' who were driven by selfinterest and lacked authenticity. The career trajectory was clear: early engagement in student politics, recruitment as a ministerial adviser or party worker, followed by preselection into a safe seat:

I feel like a lot of the generation of the current political leaders grew up in a system where they enter politics at a very young age, affiliate with a party, work up through the party apparatus, and they are incredible political animals. They know the system, but I feel that it is that self-serving element which becomes the primary concern, rather than that more sort of idealistic idea of 'serving the community’. (Focus Group 9)

The distinction here is between incumbent career politicians who serve at the pleasure of their party and amateur politicians who come from outside the system. Career politicians were seen to be entering into a 'Faustian bargain' in which they sacrificed their principles in order to benefit from power and a guaranteed job for life. Our participants were extremely critical of this trade-off equating it with the emergence of a self-interested, dishonest and disingenuous political class. Complaints in this area 
ranged from "Don’t wear suits. Wear normal clothes" (Focus Group 5) to "They're essentially all old white men" (Focus Group 12). One participant summarized the overall sentiment:

No matter what level of politics you are at ... it's very, very similar ... I couldn't trust them ... it [is] spin, or self-interest ... it's too contaminated, what they argue, what they purport to stand for. (Focus Group 4)

These same views could be found in our interviews, although senior civil servants were also more likely to speak directly about the factional system and why politicians might put career ahead of principles. ${ }^{6}$ The factional system was seen as being responsible for driving a 'particular kind of behaviour...very tactical decision-making.' Factionalism was further viewed as 'a product of our system', rather than as 'a reflection on individuals', but politicians were also seen as being hamstrung by it. Whilst it imposed discipline this also came at a cost because it rewarded "people in the party who are compliant'. The politicians who maintained this system were described as 'machine politicians' who were only interested in knowing 'how you manipulate or buy or neutralize your opponents'. It was 'power being exercised by people who are absolutely faceless...it's not politics, but it's called politics' yet their position was being strengthened by the fact that 'people [are] wanting to get into it [politics] more for power than public service.'

Senior civil servants also spoke about what motivates politicians to progress their own careers. Most argued that politicians soon realized that gaining higher office was 'the only way that they can realize their passion for change which [is what] brought them to the job in the first place'. As such, a 'careerism takes hold' in which 'everyone fights 
it through, whether they say it or not.' Interviewees also saw this as a self-reinforcing process because: 'the further you go into it, the more you can do it my way. The right way.' Some participants noted that higher ministerial turnover and frequent reshuffles helped fuel this tendency. Our participants often contrasted this situation with amateur politicians who entered politics out of a 'dutiful concern' to represent the views of the ordinary man or woman 'on the street' or following a successful career in another field. Amateur politicians could speak out and were are not all 'cast from the same mould'.

However, having made this distinction, participants also recognized the need for professionalism. For example, the party system was a double-edged sword: necessary for governing competence at the same time as it stopped politicians from saying what they really thought. Many participants argued that a sensationalist media compounded this dilemma by being all too keen to jump on any hint of a division within the party. ${ }^{7}$ Our participants compared this with amateur politicians who were less likely to be motivated by self-interested yet also less capable of exercising effective authority and decision-making power.

\section{Working Competencies}

Professionalization was also taken to mean working competencies and having the necessary skillset to be an effective politician. Whilst professional politicians were expected to be trained 'political animals', amateur politicians were either 'intelligent' independents or 'everyday' amateurs. Most of our participants expected professional politicians to be trained in the 'craft of politics' and the process of reaching 'good accommodations'. In the words of one interviewee: 'it is all about negotiation'. Interviewees noted how this often required the ability to "cobble together a coalition of 
some description' that also necessitated a certain 'personal camaraderie' to exist beyond the purely party political. The 'craft of politics' also required a strong sense of self-belief, which could often lapse into 'arrogance' or a 'dissociative sort of tendency'. Other interviewees noted how the 'straightjacket' imposed by 'the party line' and the 'need to stay on message' had made this craft all the more difficult.

Whilst professional politicians benefitted from working within an organizational hierarchy, this would only become apparent after a long-established career in which they had learnt how to 'climb the greasy pole'. Interviewees also noted how ministers, in particular, needed to be good at making decisions because 'nearly every brief requires a decision to be taken' at a time when there's 'disproportionate information coming in and many more demands to make decisions'. But, professional politicians also need to be able to communicate their decisions in a convincing way so that it didn't look like they were either 'bullshitting' or 'just pumping out...their lines for the day'.

By contrast, amateur politicians were characterized as valuing independent thought and 'common sense' decision-making. They were also much more likely to develop a 'personal connection' with voters. So, whilst they may possess some technical knowledge from their previous life experience, they were much more likely to forefront either their personal experience based on their previous professional career or their 'everyday' characteristics as an average 'bloke on the street'. As one senior civil servant commented: 'People say no one's giving much of a rats about me anymore, it's all this stuff that I can't connect with. I'll boot them ... Pauline [Hanson], I understand what she's saying, and she's talking about stuff that's here and now for me.' 
These characteristics also filtered into discussions about politicians and their working competencies. The participants in our focus groups argued that professional politicians were expected to perform almost flawlessly as 'consummate professionals' adhering to the very highest ethical standards and levels of governing competence. This expectation was heightened for career politicians precisely because they were viewed as seasoned and experienced professionals:

I feel that politicians should be able to handle themselves well and articulate a position well in any circumstance. Again, they're not like every other job. I place a very high level of pressure or expectation on that person. (Focus Group 9)

Conversely, the appeal of amateur politicians lay more on trust, rather than competence: I like people who've gone and done other things and realize a calling ... whenever I end up finding out about a politicians history and if it's something quite outside of politics, I'm like "oh okay. That's kind of interesting" and I find I naturally trust them more. (Focus Group 7)

The paradox here is that, whilst our participants recognized that professional politicians were destined to fail against the 'superhuman standards' against which they were being evaluated, they also accepted this contradiction and remained largely unconcerned by it. Conversely, our interviewees saw it as a key issue. Senior civil servants noted that it often originated with the politicians themselves who always 'feel that they have to have the answers' because the lack of an answer would be an admission of their own fallibility. This meant that politicians raised 'unrealistic expectations...they come out and say to the common person, "Leave your problems to me. I'll fix them, you go to the pub." This senior civil servant went onto argue that the political process has 
compounded this phenomenon because it has become an increasingly 'marginal business' in which 'most of the levers of control are gone. Politicians pretend or believe that they can change these things when they can't'. As a different interviewee commented: 'I think it's probably worth having a conversation about the fact that government can't fix everything...[But] That goes against the very being of politicians, doesn't it?'

In the focus groups, participants spoke of similar tensions but with reference to the 24hour media cycle. In this framing, participants argued that the changing nature of the media and pressure to sell newspapers meant that outlets were intent on exposing conflict or failure, rather than compromise or success. Participants agreed that anyone could be made to look bad with this level of scrutiny but our focus group participants still expected professional politicians to find some way through this tension in the same way as other professional groups who actively court the media:

How the media deals with politicians, it's no different from, again, how media deals with celebrities and stuff. They're ruthless when the politicians make a mistake ... They come up with all these sensational stuff. (Focus Group 3)

The important message here is that despite some differences, our participants were still overwhelmingly critical of professional politicians for both being too media savvy at the same time as being not media savvy enough. Conversely, whilst amateur politicians were viewed as more trustworthy our participants also voiced concerns about whether their role as an honest broker could survive in the more mediatized world in which we are living. 


\section{Working Values}

All of our participants wanted their politicians to act with honour and integrity and to adhere to 'professional' standards such as transparency, openness, and accountability. Many senior civil servants, in particular, commented on the need for politicians to stick to a 'core set of values' or 'foundational ideology'. But, whilst our participants believed that politicians should follow the same norms and standards as any other profession, most also recognized that politics was a somewhat exceptional occupation:

people expect politicians to know all the solutions ... that's huge pressure and that's not a normal job. That's sort of being the God of the world. (Focus Group 5)

Here, we saw a change in views throughout our focus groups as our participants transitioned from fast to slow thinking. In the case of professional politicians, selfinterest, incumbency and corruption gave way to an overwhelming sense that most people probably enter politics for well-meaning and honourable reasons but it is the nature of the 'political system' that inevitably corrupts them. One respondent summarized this argument particularly succinctly:

My first one is self-preservation. It's because when they go into these jobs...They may have ideals but they... get into this cycle where they have to please everyone to be re-elected because their livelihood depends on it ...They can't go out on a limb. They can't fight for what they really believe in ... and in that way they pretty much can't change anything. (Focus Group 11)

Indeed, many respondents argued that the more senior you are, the more compromised you become. Our respondents saw this as particularly problematic: effecting real 
change relied on seniority yet gaining seniority within the party hierarchy relied on politicians forfeiting their principles. This argument accorded politicians more empathy at the same time as it engendered a greater degree of cynicism:

I have actually met politicians before and I don't think that they're different to most people. I think that if we were put in that position then we would probably make the same decisions that they do... A lot of them are very ambitious. It wouldn't surprise me if every single one wants to become Prime Minister, and they over-promise. I wouldn't necessarily think they're always lying but I would say that there's a good number of politicians that just don't understand the reality until it hits them, until they get into power and realize, "Oh shit, we can't do this." (Focus Group 11)

Senior civil servants also spoke about new ministers getting 'very despondent' after their first year in the job once they had come to realize the limits of their power. In our focus groups, this was discussed with respect to 'the system'. Many echoed the view that: 'You can't trust the system. You can't trust the person because someone's got their balls' (Focus Group 6). One senior civil servant referred to an instance in which politicians had successfully achieved cross-party support on a Parliamentary Committee report only for it to be withdrawn once factional leaders intervened: 'They didn't agree with the position that they'd been ordered to take, but they took it'.

Conversely, amateur politicians were viewed as genuine, better able to represent their constituents, direct and willing to defend unpopular and non-conformist views because they worked outside 'the system': 
It's interesting, politicians, like Nick Xenophon [an independent Senator], who presumably didn't have any aspirations ten years ago to get into politics. Then you see him taking up a minority agenda and it's refreshing to see someone like that ... [it] gives his position a little bit more value and validity, rather than someone who's worked up the ranks through the Young Liberals. It's just really cool having an ordinary person. Hopefully he'll be more in touch than other career politicians. (Focus Group 4)

Many respondents implored professional politicians to demonstrate the same genuineness, honesty and freedom to 'tell it as it is'. Senior civil servants raised related concerns when they spoke about the need for ministers to be willing to listen to alternative or dissenting advice. One interviewee spoke about there being 'loads of hurdles' to getting information to the minister whilst another spoke about 'massaging things so the minister will be pleased rather than telling the nasty truth'. Some senior civil servants also spoke about how this can evolve into a situation where politicians actively resist dissenting opinion: 'Uncertainty about what you're doing, or where you stand, or what you want to do, is not viewed as power in that world. It's seen as a weakness'. Other interviewees spoke about 'very ideologically-driven ministers', which meant that 'people don't even put up the good advice anymore'.

Whilst our participants found amateur behaviour refreshing, they also acknowledged that the political process often required compromise and negotiation. Indeed, what participants really favoured were politicians who could demonstrate both professionalism and amateurism. For example, one respondent, spoke favourably about a career politician who got this balance right: 
When I listened to Penny Wong do a massive speech in Parliament relating [to] ... higher education regulation; she was very candid and presented her viewpoint very well. I thought there was a genuine element to what she was saying. I trusted her values and her judgment because I felt she was being genuine. (Focus Group 9)

In sum, our participants wanted more professional leaders, despite believing that they could trust amateur politicians more. They expected their politicians to be loyal, unified and achieve change through the existing political structure. But, they also valued amateur politicians for their independence, frankness and autonomy; and these were all features that reinforced their confidence in that politician's personal integrity, ethics and working values. They were aware that they were putting politicians in a 'double bind' but managing this double bind was what marked out a 'good' politician from a 'bad' one.

\section{Working Conditions}

Working conditions refers to the salary, pensions, expenses and other entitlements received by politicians. Politicians' salaries generated considerable debate in our focus groups, as this exchange illustrates:

\section{Participant 1:}

No [it's not an ordinary job]. It's paid far too little to be any other job. It's people that have been successful and want to give back. The question then becomes, how do they give back and can they?

Participant 2: 
Is it that little? I thought it was senators were getting almost two hundred thousand dollars [a year]?

Participant 3:

Everybody gets John's point: if you compare the responsibility they [politicians] have to an executive in a bank, [the] problem is five-hundred thousand a year is nothing compared to that. What, twelve million dollars?

Participant 2:

Macquarie bank CEO...Paid peanuts get monkeys.

Participant 1:

They're under constant scrutiny...

Participant 2:

It's still comfortable pay comparably.

(Focus Group 10)

Whilst this exchange shows a lack of knowledge about politicians and their pay, it also illustrates differences in view about what the appropriate level of pay should be. ${ }^{8} \mathrm{~A}$ parallel between ministerial pay and CEO pay was frequently raised in the focus groups whilst others argued that pay should be irrelevant because those who go into politics should be motivated by more virtuous reasons.

This tension was particularly evident in discussions about whether politicians delivered 'value for money'. Our focus group participants accepted that professional politicians should receive salaries and perks in return for working long hours. Indeed, this occasionally verged on empathy towards politicians and their constant exposure in the public eye, the work pressure, the travel and the long hours. However, all of these 
additional strains were seen as self-inflicted 'lifestyle choices' and not that much different from the type of sacrifices that you might expect from other professional groups.

Conversely, our interviewees were almost always more empathetic towards politicians and their working conditions. One senior civil servant described politics as a 'difficult game' in which you have to 'work bloody hard'. As a politician, 'you can't necessarily do anything else in your life', you need to be 'thick skinned', 'tough' and 'very resilient'. The working week is 'relentless', 'overwhelming and all-consuming'. It all added up to a 'pretty punishing sort of life' in which you are 'never off' and where 'very rarely...[do you get] appreciated or applauded for good things'. Politicians also need to be able to 'hold down multiple jobs' whilst living a 'precarious existence' in which 'everyone's worried about the next election'. The 'pressure cooker' environment that this creates means that you constantly have to keep up a 'brave front' because once you let people 'know you're vulnerable, you're exposed...all bets are off.' Politicians even those in the same party - can't talk or confide in one another because 'one is after the other one's job'. Overall, this makes for a lonely existence: 'You're flying all the time. You live in a bubble... It can be very lonely and very isolating.'

This was quite different from when politicians were viewed as amateurs where the perks and privileges of working in politics were seen as having a corrupting influence. This view often centred on a tension between acting for the public good and being well remunerated for it, which is captured by the following exchange: ${ }^{9}$

Participant 1: 
I'm sort of negative, but I also think personal reasons, like incentives, can draw you into it. There's the whole money, and the perks, especially with stuff that's going on at the moment and it's-

Participant 2:

A helicopter.

Participant 1:

Yeah, helicopter rides and the status that you get from saying that you're a politician and having a level of influence over how things are done. I see it as maybe it could be money-driven in some cases and the perks and everything you get from going down that career path, rather than actually wanting it because you're passionate about representing 'the people'.

Participant 3:

All those parties you get invited to.

Participant 1:

Yeah: that you can claim all these expenses.

(Focus Group 11)

So, working conditions is one final dimension in which the tensions towards professionalism were evident between when remuneration represents adequate compensation or a corruptible influence.

\section{Conclusion: acting like professionals but paid like amateurs}

These findings have considerable implications for how we think about professionalization and rising political disaffection, from both the 'demand' and 'supply' side. Demand-side explanations posit that if citizens understood politics better 
they would be more accepting of inevitable failures. We can infer from this that civil servants, who are both intimately involved in the processes and practices of democratic government and professionals in the modern sense of that word, ought to be more sympathetic to politicians, including the rewards and entitlements that they receive. Some are. Certainly, those who work with politicians at a senior level appear more aware of the contradictory expectations and pressures that politicians work under. But, junior civil servants had much less sympathy. Given that members of the public, no matter how good their knowledge about politics and public affairs, are unlikely to have the type of intimate, first hand, experience of life at the apex of government as senior civil servants, this is a sobering finding for those who advocate for demand-side solutions as an answer to the problem of rising democratic disaffection (see also Corbett 2015).

Our findings also have implications for the main 'supply-side' theories. We might expect that civil servants, as professional 'insiders', would be less concerned that politicians come from markedly different backgrounds to the general electorate. But, this was rarely the case. Instead, our focus groups revealed that the amateur politician was seen as a solution to the current democratic malaise. This questions the claim that having a more representative legislature would reduce disaffection. Whilst some of our respondents noted the need for more women and younger representatives, our respondents placed a higher value on governing competence, technical skills and professional norms and standards of conduct. In part, we might infer that this reflects their values as professionals. But, it also shows a capacity to hold seemingly irreconcilable beliefs in tension: they want politicians to be both 'like them' but also 'better' than them (cf. Medvic 2013). 
The alternative 'supply-side' claim is that politicians are distrusted because they are implicated in the neo-liberal project of depoliticization. We certainly found that civil servants were deeply concerned about politicians promising too much and the political system's capacity to corrupt. Respondents also relayed that they were cynical about the hidden hand of moneyed interests in the party-political process. Senior civil servants suggested that politicians needed to show more humility by focussing on those things that they can fix and acknowledging those over which they have little control. But, our respondents also placed a high value on politicians who could 'work' the system and 'bend' the rules of the game: they wanted politicians who appeared authentic but who could also manipulate the media cycle towards their own ends. Perhaps most challengingly, they seemed to endorse professionals on the grounds that they could $d o$ more but also amateurs on the grounds that they would cost less.

Combined, these findings present a destabilising picture for established ways of thinking about the anti-politician problem and its potential solutions. We can plausibly imagine a counterfactual scenario to all three of the main propositions in the existing literature in which citizens are disaffected with 'amateur' politics in much the same way as they bemoan professionalism and rising careerism today. More empirical work is required to substantiate this claim; we would not want to rely solely on the views of civil servants, but, as an initial step, their views have proven to be incredibly revealing.

The findings could also be further substantiated via a cross-national analysis. Having said that, whilst our results are drawn from Australian data, Table 2 is presented at a level of abstraction that could plausibly be applied elsewhere (cf. Dowding 2017). A 
longitudinal analysis of the type undertaken by Moss et al. (2016) could further tease out these trends over time. And, both types of work can assist with the generation of questions for public surveys that better reflect the multiple meanings and dimensions of professionalization. For now, however, our aims were both more modest but also more fundamental: to shed empirical light on an often claimed but rarely interrogated thesis that the professionalization of the political class is a root cause of rising antipolitician sentiment.

We concede that our core finding - that citizens want politicians who act like professionals but are paid like amateurs - is a sobering one, not least because most of our participants were aware, but remained largely unconcerned, by the contradiction. This finding may reflect the nature of our data and the capacity of focus groups to highlight disjuncture and disagreement, rather than a consolidated opinion. But, the corresponding strength of this type of data is that we also encountered an alternative and more empathetic narrative that revolved around the idea that we can understand politicians better by acknowledging the environment that they work within. We conclude by discussing this point and its normative implications.

By encouraging a process of reflection and deliberation, our data also reveals that, in some instances, recognition of the contradictions that politicians labour under could engender or elucidate a degree of empathy (cf. Boswell and Corbett 2017). This empathy was certainly not forthcoming in all of our participants but we did observe elements of it across all of our focus groups and the interviews. The capacity to empathize with politicians offers considerable potential for the normative agenda concerned with reviving faith in the political system (Fawcett 2014). As Kane and 
Patapan (2012) highlight, reflexive recognition of the inherent problems that politicians labour under has the potential to temper our expectations of democracy because it reduces the perpetual cycle in which naive hope is replaced by cynical despondency (as each new leader turns out to be just as flawed as their predecessor). What our data reveals is how this might be achieved. Knowledge and awareness of how the political system works is not enough - indeed, it can be counterproductive - but focusing on engendering reflexivity offers considerable potential (cf. Stoker et al. 2016). Our focus groups did not specifically aim to direct participants towards a particular outcome in the manner that deliberative democrats in particular advocate. But, the process of facilitated deliberation did lead some to reconsider their views. Our interviewees also exhibited reflexivity as they reflected back on their own experience. Again, further empirical work is required to bear this out. For now, we conclude by pointing to engendering reflexivity as a tentative way forward. In doing so, we offer a slither of hope for all of those who believe in the centrality of politicians in modern representative democracies. 


\section{Notes}

${ }^{1}$ The APS is the civil service of the Commonwealth of Australia meaning that all of the participants in this study worked at the federal level of government.

${ }^{2}$ Whilst this statement captures the general trend, it is also important to note several exceptions. For example, Bean (2015), has also argued that, whilst confidence in Australia's political institutions has never been high, neither has it undergone an unremitting decline.

${ }^{3}$ The Australian Election Study is a nationally representative survey of voters that has been running since 1987.

${ }^{4}$ Leigh $(2002,47)$ has described Roy Morgan Poll data as 'the most reliable data on attitudes towards Australian politicians'.

${ }^{5}$ In the first tranche, we invited 25 senior civil servants to participate in the study. Ten replied to the invitation. We then worked up to 15 interviews using the snowballing technique.

${ }^{6}$ The factional system is a crucial feature of the Australian party political system (see Leigh 2000; Mills 2013).

${ }^{7}$ The term 'many' is used to refer to more than three interviewees or repeated verbal references to the same issue within a focus group discussion. In both cases, this is based on analysis of the written transcript itself, rather than physical or emotional reactions within the focus groups or interviews (which do not form part of the data analysed in this study).

${ }^{8}$ The base salary for parliamentarians is $\$ 199,040$ per annum (from 1 January 2016). Ministers of state and parliamentary office holders receive an additional salary on top of this base salary. Parliamentarians are also able to access various entitlements related to 'parliamentary or electorate business' (Parliament of Australia 2016).

${ }^{9}$ In this extract, the discussion about 'helicopter rides' refers to the resignation of Bronwyn Bishop, the Speaker of the House of Representatives. In August 2015, Bishop came under media pressure over her use of travel entitlements after it was revealed that she had spent more than $\$ 5,000$ chartering a helicopter from Melbourne to Geelong to attend a Liberal Party fundraiser (ABC 2015).

\section{References}

Abbott, A. (2014). The system of professions: An essay on the division of expert labor. Chicago: University of Chicago Press.

Albertazzi, D., \& McDonnell, D. (2015). Populists in power. London: Routledge.

Allen, N., \& Birch, S. (2011). Political conduct and misconduct: probing public opinion. Parliamentary Affairs, 64(1), 61-81.

Allen, P., \& Cairney, P. (2015). What do we mean when we talk about the 'political class'? Political Studies Review, 15(1), 18-27.

Australian Broadcasting Corporation (2015). Bronwyn Bishop resigns as Speaker; Tony Abbott announces review of entitlements system. 
http://www.abc.net.au/news/2015-08-02/bronwyn-bishop-stands-down-asspeaker/6666172. Accessed 20 March 2017.

Barber, S. (2014). Arise, Careerless Politician: The Rise of the Professional Party Leader. Politics, 34(1), 23-31.

Bean, C. (2015). Changing Citizen Confidence: Orientations towards Political and Social Institutions in Australia, 1983-2010. The Open Political Science Journal, 8, 19.

Bean, C. S. (2012). Are we keeping the bastards honest? Perceptions of corruption, integrity and influence on politics. In J. Pietsch, \& H. Aarons (Eds.), Australia: Identity, Fear and Governance in the 21st Century (pp. 95-106). Canberra: Australian National University E Press.

Beckman, L. (2007). The professionalisation of politics reconsidered. A study of the Swedish Cabinet 1917-2004. Parliamentary Affairs, 60(1), 66-83.

Beetham, D. (Ed.) (2006). Parliament and democracy in the twenty-first century: A guide to good practice. Geneva: Inter-Parliamentary Union.

Best, H., \& Higley, J. (Eds.) (2010). Democratic Elitism: New Theoretical and Comparative Perspectives. Leiden: Brill.

Borchert, J., \& Zeiss, J. (2003). The political class in advanced democracies: A comparative handbook. Oxford: Oxford University Press.

Boswell, J., \& Corbett, J. (2015). Stoic democrats? Anti-politics, elite cynicism and the policy process. Journal of European Public Policy 22(10), 1388-1405.

Boswell, J., \& Corbett, J. (2017). Deliberative bureaucracy: reconciling democracy's trade-off between inclusion and economy. Political Studies, https://doi.org/10.1177/0032321717723512.

Boswell, J., Corbett, J., Dommett, K., Jennings, W., Flinders, M., Rhodes, R.A.W., \& Wood, M. (2018). State of the Field: What Can Political Ethnography Tell Us about Anti-Politics and Democratic Disaffection? European Journal of Political Research, https://doi.org/10.1111/1475-6765.12270.

Brett, J., \& Moran, A. (2006). Ordinary people's politics. Australians Talk about Life, Politics and the Future of their Country. Melbourne: Pluto.

Burchell, D., \& Leigh, A. (Eds.) (2002). Prince's New Clothes: Why Do Australians Dislike Their Politicians? Sydney: UNSW Press.

Cairney, P. (2007). The professionalisation of MPs: Refining the 'politics-facilitating' explanation. Parliamentary Affairs 60(2), 212-233. 
Cameron, S. M., \& McAllister, I. (2016). Trends in Australian Political Opinion: Results from the Australian Election Study 1987-2016. Canberra: The Australian National University.

Campbell, R., \& Cowley, P. (2014). What Voters Want: Reactions to Candidate Characteristics in a Survey Experiment. Political Studies 62(4), 745-765.

Clarke, N., Jennings, W., Moss, J., \& Stoker, G. (2018). The Good Politician: Folk Theories, Political Interaction, and the Rise of Anti-Politics. Cambridge: Cambridge University Press.

Coghill, K., Colleen L., \& Steinack, K. (2012). How should elected members learn parliamentary skills: an overview. Parliamentary Affairs 65(3), 505-519.

Coghill, K., Sampford, C. J. G., \& Smith, T. (Eds.) (2012). Fiduciary Duty and the Atmospheric Trust. London: Routledge.

Corbett, J. (2015). Being Political: Leadership and democracy in the pacific islands. University of Hawai'i Press.

Corbett, J. (2016). Diagnosing the problem of anti-politicians: A review and an agenda. Political Studies Review, 14(4), 534-543.

Cowley, P. (2014). Descriptive Representation and Political Trust: A Quasi-natural Experiment Utilising Ignorance. The Journal of Legislative Studies, 20(4), 573-587.

Crosby, S. (2016). The Trust Deficit. Melbourne: Melbourne University Press.

Curato, N., Dryzek, J. S., Ercan, S. A., Hendriks, C. M., \& Niemeyer, S. (2017). Twelve Key Findings in Deliberative Democracy Research. Daedelus, 146(3), 28-38.

Cyr, J. (2016). The Pitfalls and Promise of Focus Groups as a Data Collection Method. Sociological Methods \& Research, 45(2), 231-259.

Dickenson, J. (2013). Trust Me: Australian Voters and Their Politicians. Sydney: UNSW Press.

Dowding, K. (2017). Australian exceptionalism reconsidered. Australian Journal of Political Science, 52(2), 165-182.

Edelman Trust Barometer. 2017. Trust Free-Falls in the Land Down Under. https://www.edelman.com/post/trust-free-falls-in-the-land-down-under/. Accessed 20 March 2017.

Eggers, A. C., \& Hainmueller, J. (2009). MPs for sale? Returns to office in postwar British politics. American Political Science Review, 103(04), 513-533.

Evans, M., \& Stoker, S. (2016). Political participation in Australia: Contingency in the behaviour and attitudes of citizens. Australian Journal of Political Science, 51(2), 116. 
Evetts, J. (2013). Professionalism: Value and ideology. Current Sociology, 61(5-6), 778-796.

Fawcett, P. (2014). Can't Live With Them, Can't Live Without Them: Why Politicians Matter. Democratic Theory, 1(2), 67-75.

Fawcett, P., Flinders, M., Wood, M, \& Hay, C. (Eds.) (2017). Anti-politics, Depoliticization, and Governance. Oxford University Press.

Flinders, M. (2012). Defending Politics: Why democracy matters in the 21st century. Oxford: Oxford University Press.

Flinders, M., \& Buller, J. (2006). Depoliticisation: principles, tactics and tools. British Politics, 1(3), 293-318.

Gauja, A. (2015). The State of Democracy and Representation in Australia. Representation, 51(1), 23-34.

Hay, C. (2007). Why we hate politics. Cambridge: Polity.

Hay, C., \& Stoker, G. (2009). Revitalising politics: have we lost the plot? Representation, 45(3), 225-236.

Hibbing, J. R., \& Theiss-Morse, E. (2002). Stealth democracy: Americans' beliefs about how government should work. Cambridge: Cambridge University Press.

Hill, J. G. (2012). Why did Australia fare so well in the global financial crisis? In E. Ferran, N. Moloney, J. G. Hill, \& J. C. Coffee (Eds.), The Regulatory Aftermath of the Global Financial Crisis (pp. 203-300). Cambridge: Cambridge University Press.

Howarth, D. R. (2013). Reaching the Cabinet: A British Cursus Honorum? Available at http://dx.doi.org/10.2139/ssrn.2221921.

Jones, K. (2005). Politicians and Political Cynicism More or Less? Australasian Parliamentary Review, 20(2), 116-129.

Jones, K. (2008). Professional Politicians as the Subjects of Moral Panic. Australian Journal of Political Science, 43(2), 243-258.

Kahneman, D. (2011). Thinking, fast and slow. New York: Farrar, Straus and Grioux.

Kane, J., \& Patapan, H. (2012). The democratic leader: How democracy defines, empowers and limits its leaders. Oxford: Oxford University Press.

Kelley Jr, S. (1998). Politics as a Vocation: Variations on Weber. In J. Geer (Ed.) Politicians and Party Politics (pp. 337-364). Baltimore: Johns Hopkins University Press. 
King, A. (1981). The Rise of the Career Politician in Britain-and Its Consequences. British Journal of Political Science, 11(3), 249-285.

Lafitte, P. (1958). Social Structure and Personality in the Factory. London: Routledge \& Kegan Paul.

Lapinski, J., Levendusky, M., Winneg, K., \& Jamieson, K. H. (2016). What Do Citizens Want from Their Member of Congress? Political Research Quarterly, 69(3), 535-545.

Leigh, A. (2000). Factions and Fractions: A Case Study of Power Politics in the Australian Labor Party. Australian Journal of Political Science, 35(3), 427-448.

Leigh, A. (2002). Explaining distrust: Popular attitudes towards politicians in Australia and the United States. In D. Burchell and A. Leigh (Eds.), Prince's New Clothes: Why Do Australians Dislike Their Politicians? (pp. 47-61). Sydney: UNSW Press.

Lewis, C., \& Coghill, K. (Eds.) (2016), Parliamentarians' Professional Development: The Need for Reform. Geneva: Springer International Publishing.

Marsh, D., Vines, E., \& Halupka, M. (2016). Two Cheers for Richards and Smith: Beyond Anti-Politics? Political Quarterly, 87(3), 383-388.

Marsh, I., \& Miller, R. (2012). Democratic Decline and Democratic Renewal: Political Change in Britain, Australia and New Zealand. Cambridge: Cambridge University Press.

Martin, A. (2012). Political participation among the young in Australia: testing Dalton's good citizen thesis. Australian Journal of Political Science, 47(2), 211-226.

Mayer, H., Lovedy, P., \& Westerway, P. (1960). Images of Politics: an analysis of letters to the press on the Richardson Report. Australian Journal of Politics \& History, $6(2), 153-175$.

McDonnell, D. (2015). Populist Leaders and Coterie Charisma. Political Studies, 64(3), 719-733.

Medvic, S. K. (2013). In defense of politicians: The expectations trap and its threat to democracy. London: Routledge.

Mills, S. (2013). The professionals: Strategy, money and the rise of the political campaigner in Australia. Collingwood, VIC: Black Inc..

Moss, J., Clarke, N., Jennings, W., \& Stoker, G. (2016). Golden age, apathy, or stealth? Democratic engagement in Britain, 1945-1950. Contemporary British History, 30(4), 441-462.

Mudde, C. (2007). Populist Radical Right Parties in Europe. Cambridge: Cambridge University Press. 
Mudde, C. (2013). Three decades of populist radical right parties in Western Europe: So what? European Journal of Political Research, 52(1), 1-19.

Neblo, M. A., Esterling, K. M., Kennedy, R. P., Lazer, D. M., \& Sokhey, A. E. (2010). Who wants to deliberate - and why? American Political Science Review, 104(03), 566583.

Negrine, R., \& Bull, P. (2015). "Mr Malik, to Represent the People of Dewsbury Do You Need a $£ 2600$ Cinema System Paid for by the Taxpayer?": An Analysis of British Television News Coverage of the 2009 MPs Expenses Scandal. Parliamentary Affairs, 68(3), 573-591.

Noordegraaf, M. (2007). From "Pure" to "Hybrid" professionalism: Present-day professionalism in Ambiguous public Domains. Administration \& Society, 39(6), 761785.

Norris, P. (2011). Democratic deficit: Critical citizens revisited. Cambridge: Cambridge University Press.

Papadakis, E. 1999. Constituents of Confidence and Mistrust in Australian Institutions. Australian Journal of Political Science, 34(1), 75-93.

Papadopoulos, Y. (2013). Democracy in crisis?: politics, governance and policy. Houndmills: Palgrave Macmillan.

Parliament of Australia (2016), Parliamentary remuneration and entitlements: 2016 update.

https://www.aph.gov.au/About Parliament/Parliamentary Departments/Parliamentary Library/pubs/rp/rp1516/ParlRem2016\# Toc406579729. Accessed 20 March 2017.

Putnam, R. D. (2001). Bowling alone: The collapse and revival of American community. New York: Simon and Schuster.

Riddell, P. (1996). Honest Opportunism: How We Get the Politicians We Deserve. London: Indigo.

Riddell, P. (1995). The impact of the rise of the career politician. The Journal of Legislative Studies, 1(2), 186-191.

Roy Morgan (2017) Roy Morgan Image of Professions Survey 2017: Health professionals continue domination with Nurses most highly regarded again; followed by Doctors and Pharmacists. http://www.roymorgan.com/findings/7244-roy-morganimage-of-professions-may-2017-201706051543. Accessed 20 March 2017.

Rush, M., \& Giddings, P. (2011). Parliamentary Socialisation: Learning the Ropes or Determining Behaviour? Springer.

Smithson, J. (2000). Using and analysing focus groups: limitations and possibilities. International Journal of Social Research Methodology, 3(2), 103-119. 
Stoker, G. (2006). Why politics matters: making democracy work. Houndmills: Palgrave Macmillan.

Stoker, G., Colin H., \& Barr, M. (2016). Fast thinking: Implications for democratic politics. European Journal of Political Research, 55(1): 3-21.

Stoker, G., Li, J., Halupka, M., \& Evans, M. (2017). Complacent young citizens or cross-generational solidarity? An analysis of Australian attitudes to democratic politics. Australian Journal of Political Science, 52(2), 218-235.

Vromen, A., Loader, B. D., Xenos, M. A., \& Bailo, F. (2016). Everyday Making through Facebook Engagement: Young Citizens' Political Interactions in Australia, the United Kingdom and the United States. Political Studies, 64(3), 513-533.

Weber, M. (1968). Politics as a Vocation. Philadelphia: Fortress Press.

Wilensky, H. L. (1964). The professionalisation of everyone? American Journal of Sociology, 70(2), 137-158.

Wood, M., \& Flinders, M. (2014). Rethinking depoliticisation: Beyond the governmental. Policy \& Politics, 42(2), 151-170. 


\section{Data Appendix}

\section{Background Information}

Table 1: Focus Groups

\begin{tabular}{|c|c|c|c|}
\hline $\begin{array}{c}\text { Focus Group } \\
\text { Number }\end{array}$ & Type & $\begin{array}{c}\text { Number of Civil } \\
\text { Servants }\end{array}$ & $\begin{array}{c}\text { Length } \\
\text { (mins) }\end{array}$ \\
\hline $\mathbf{1}$ & Focus Group & 4 & 60 \\
\hline $\mathbf{2}$ & Focus Group & 7 & 80 \\
\hline $\mathbf{3}$ & Focus Group & 4 & 76 \\
\hline $\mathbf{4}$ & Focus Group & 3 & 44 \\
\hline $\mathbf{5}$ & Focus Group & 5 & 50 \\
\hline $\mathbf{6}$ & Focus Group & 4 & 55 \\
\hline $\mathbf{7}$ & Focus Group & 6 & 62 \\
\hline $\mathbf{8}$ & Focus Group & 5 & 59 \\
\hline $\mathbf{9}$ & Focus Group & 5 & 48 \\
\hline $\mathbf{1 0}$ & Focus Group & 7 & 56 \\
\hline $\mathbf{1 1}$ & Focus Group & 5 & 44 \\
\hline $\mathbf{1 2}$ & Focus Group & 4 & 37 \\
\hline Total & - & $\mathbf{5 9}$ & $\mathbf{6 7 1}$ \\
\hline Average & - & $\mathbf{4 . 9}$ & 45 \\
\hline $\mathbf{1 3}$ & Debrief & 6 & 46 \\
\hline $\mathbf{1 4}$ & Debrief & 3 & $\mathbf{5 6}$ \\
\hline
\end{tabular}

Table 2: Interviews

\begin{tabular}{|c|c|c|c|}
\hline $\begin{array}{c}\text { Interview } \\
\text { Number }\end{array}$ & Interview Date & $\begin{array}{c}\text { Central/Line } \\
\text { Agency }\end{array}$ & $\begin{array}{c}\text { Length } \\
\text { (mins) }\end{array}$ \\
\hline 1 & 14 November 2016 & Central & 22 \\
\hline 2 & 30 November 2016 & Line & 53 \\
\hline 3 & 2 December 2016 & Line & 58 \\
\hline 4 & 2 December 2016 & Central & 92 \\
\hline 5 & 6 December 2016 & Central & 75 \\
\hline 6 & 6 December 2016 & Line & 62 \\
\hline 7 & 7 December 2016 & Line & 79 \\
\hline 8 & 8 December 2016 & Line & 57 \\
\hline 9 & 13 December 2016 & Line & 62 \\
\hline 10 & 18 January 2017 & Central & 68 \\
\hline 11 & 19 July 2017 & Central & 56 \\
\hline 12 & 25 August 2017 & Line & 61 \\
\hline 13 & 29 August 2017 & Line & 118 \\
\hline 14 & 29 August 2017 & Central & 95 \\
\hline 15 & 29 August 2017 & Central & $\mathbf{1 0 1 7}$ \\
\hline Total & - & - & $\mathbf{6 8}$ \\
\hline Average & - & - & \\
\hline
\end{tabular}




\section{Topic/Question Guide}

Focus groups: The question guide was sent to the focus group facilitator at least one week in advance. The researchers and facilitators met several days before the focus group to discuss the general approach to the focus groups and how to use the topic/question guide. Focus group facilitators were advised to promote dialogue within, but not entirely confined by, the broad framework provided by the question/topic guide.

Interviews: The topic/question guide was forwarded to all interviewees at least one week in advance of the interview. They were able to amend, ignore or address all of the questions. Whilst semi-structured, the researchers used the topic/question guide as a series of prompts to help facilitate the discussion. The interviews were conducted by the researchers.

The data generated from the focus groups and interviews are linked to a broader research project on elite perceptions towards politicians. They therefore encompass other questions of relevance to this project.

Interviews only:

1. Can you please tell me about your professional experience working with politicians?

Interviews and focus groups:

2. Why do you think that some people decide to pursue a career in politics?

3. In your view, what characteristics define a 'good' politician?

4. What types of challenges and pressures do politicians face?

5. How would you describe the level of trust towards politicians?

6. Have your views about politicians changed during your career in the public service? How?

7. If politicians were to change one thing about themselves to improve your perceptions of them then what would it be?

\section{Data Analysis}

The focus groups and interviews were transcribed by a research assistant and imported into Nvivo. Coding was conducted by the two researchers and the research assistant ('the coders'). The focus groups were coded first followed by the interviews.

In the first stage, the transcripts were read and a 'long list' of codes was prepared. This 'long list' of codes was intended to capture different aspects of 'political professionalization'. 
In the second stage, any overlapping, similar or duplicate codes were identified and either removed or merged into one another. This reduced the overall number of codes and generated the terms listed in bullet point form in the table below.

In the third stage, the codes were organized into several themes concerning the different aspects of 'political professionalization' present in the focus groups and interviews. The coded data did not always fit 'neatly' into the thematic into which it had been assigned. The coders arrived at an agreed judgement in instances where this occurred whilst at the same time acknowledging that there would always be some overlap between different themes.

The coders met at regular intervals to discuss and reach agreement on their codes and their placement within certain themes. This process helped to generate a closer familiarization with the data. It also helped in moving back and forth between the data, its presentation and the conceptual discussion. In addition, for the focus groups, the transcripts from the two debriefing sessions (Focus Groups 13 and 14) were compared with the codes and themes generated from the analysis. This was also aided by the researchers having facilitated most of the focus groups themselves.

Table 3: Example Codes and Themes

\begin{tabular}{|c|c|}
\hline Theme & Example Codes \\
\hline Motivation and Recruitment & $\begin{array}{ll}\text { - } & \text { Party system/factionalism } \\
\text { - } & \text { Patronage (e.g. personal and family } \\
\text { connections) } \\
\text { - } \text { Celebrity status } \\
\text { - Vocation/calling/duty } \\
\text { - } \text { Power-seeking } \\
\text { - Incumbency ('job for life') } \\
\text { - Self-interested } \\
\text { - } \quad \text { Non-political career experience }\end{array}$ \\
\hline Working Competencies & $\begin{array}{l}\text { - } \text { Bargaining/negotiating } \\
\text { - } \text { Communication } \\
\text { - Making decisions } \\
\text { - Superhuman expectations } \\
\text { - Managing the media } \\
\text { - Working 'the system' } \\
\text { - Responsiveness }\end{array}$ \\
\hline Working Values & $\begin{array}{ll}\text { - } & \text { Career-driven/ambitious } \\
\text { - Independent } \\
\text { - Ethical } \\
\text { - } \text { Professional standards } \\
\text { - Ideological }\end{array}$ \\
\hline Working Conditions & $\begin{array}{ll}\text { - } & \text { Office support } \\
\text { - } & \text { Pay and remuneration } \\
\text { - } & \text { Training } \\
\text { - } & \text { Working hours } \\
\text { - } & \text { Perks and entitlements } \\
\end{array}$ \\
\hline
\end{tabular}




\begin{tabular}{|c|c|}
\hline Theme & Example Codes \\
\hline & - Isolation \\
\hline Other & $\begin{array}{l}\text { - Recognition of internally contradicting } \\
\text { oneself } \\
\text { - Sympathy/empathy for politicians } \\
\text { - 'Then and now' (e.g. 'the good old days') }\end{array}$ \\
\hline
\end{tabular}

